\title{
Women and Gender in 1917
}

\section{Rochelle Goldberg Ruthchild}

Let ourselves be beaten anymore? Nobody has the right now. ${ }^{1}$

Ariadna Tyrkova, 1917

1917 is the most minutely studied of any year in Russian and Soviet history. Yet despite the many books and articles devoted to the revolutions, the battlefront, and the home front, an important part of the history remains obscured. The voices of women arguing for citizenship, equality, respect, and civil rights are the often silenced or ignored sopranos and altos of Russia; without them Russian history is all bass and baritone. ${ }^{2}$ While strides have been made in making women more visible, too often they are still portrayed as having little agency. This is true both in post-Soviet and western scholarship. Consciousness about women and gender is not a matter of political correctness. It is a matter of accuracy. A full picture of 1917 must include the role of members of the majority of Russia's population as well as gender assumptions, in critical events of the year. Much progress has been made in researching and writing about women and gender in the early twentieth century, 1917, and the early Soviet period. But integrating this scholarship into the dominant narratives and classroom teaching is still problematic. This is particularly true of such key issues as the spontaneity/consciousness paradigm, class, and women's suffrage.

On both sides of the Cold War divide, the events of 1917 are still too often viewed through an androcentric and Marxist lens. Women's and gender history exists on the margins. Inspired by the resurgence of feminism in the west, historians have produced a number of works challenging this marginalization. Operating in the hyper-masculine post-Soviet space, Russian historians of women pointedly critique the new status quo. Pioneering women's historian Natalia Pushkareva hails the "revived interest in the history of the women's movement and in women's suffrage." 3 Social historian Irina Yukina notes that: "We are transitioning to a new official narrative that has shed some of its Marxist and state-centric legacies." But, she notes, that narrative "tends to occlude and obfuscate the activities of women. We are squandering an important opportunity to represent women as important participants in the

1. Ariadna Tyrkova, Osvobozhdenie zhenshchiny (Petrograd, 1917), 15, cited in Richard Stites, The Women's Liberation Movement in Russia: Feminism, Nihilism, and Bolshevism, 1860-1930 (Princeton, 1978), 293-94. The arguments in this essay are partially based on research for my book: Rochelle Goldberg Ruthchild, Equality and Revolution: Women's Rights in the Russian Empire, 1905-1917 (Pittsburgh, 2010).

2. See Rochelle Goldberg Ruthchild, "Misbehaving Women and the Russian Revolutions of 1917," ASEEES NewsNet (March 2017): 2-7.

3. Natalia Pushkareva, "Gendering Russian Historiography (Women's History in Russia: Status and” Perspectives)” in Marianna Muravyeva and Natalia Novikova, eds., Women's History in Russia: (Re) Establishing the Field (Newcastle upon Tyne, 2014), 10. 
history of civic activism and progressive movements in Russia, and in essence to rewrite political history from a gendered perspective." ${ }^{4}$

I do not seek to minimize the remarkable flowering of work about women and gender in Russian and Soviet history before, during, and after 1917. When I compiled a bibliography on works in English about women in Russia and the Soviet Union, the list totaled 875 books and articles. And that was in 1993. The subsequent Association for Women in Slavic Studies bibliography, containing works in all the European languages about the former Soviet bloc, and published just a few years later, totaled in the thousands. ${ }^{5}$

Books and articles by scholars such as Barbara Evans Clements, Linda Edmondson, Barbara Alpern Engel, Beatrice Brodsky Farnsworth, Rose Glickman, Adele Lindenmeyr, Natalia Pushkareva, Irina Yukina, Choi Chatterjee, Chris Ruane, Christine Worobec, Melissa Stockdale, and Elizabeth Wood, among others, have greatly enriched understanding of issues concerning women and gender in the early twentieth century. ${ }^{6}$ Pioneering male scholars such as Grigorii Tishkin and Richard Stites braved derision from some of their colleagues to make important contributions to the field. ${ }^{7}$ A new generation, including Sarah Badcock, Betsy Jones Hemenway, Sharon Kowalsky, Karen Petrone, and Laurie Stoff have furthered understanding of women in 1917, and its effects in the center and periphery. ${ }^{8}$

4. Irina Yukina, "Overcoming Soviet Academic Discourse in the Regions: The History of Russian Women's Movements," in Muravyeva and Novikova, eds., Women's History in Russia, 23.

5. Rochelle Goldberg Ruthchild, Women in Russia and the Soviet Union: An Annotated Bibliography (New York, 1993); Irina Livezeanu and June Pachuta Farris, eds., Women and Gender in Central and Eastern Europe, Russia, and Eurasia: A Comprehensive Bibliography, vol. 1. Southeastern and East Central Europe (Armonk, 2007); Mary Zirin and Christine Worobec, eds., Women and Gender in Central and Eastern Europe, Russia, and Eurasia: A Comprehensive Bibliography, vol. 2. Russia, the Non-Russian Peoples of the Russian Federation, and the Successor States of the Soviet Union (Armonk, 2007).

6. Including everything written by these scholars would be an article in itself, but here are their representative or recent works: Barbara Evans Clements, A History of Women in Russia From Earliest Times to the Present (Bloomington, 2012); Barbara Evans Clements, Bolshevik Feminist: The Life of Aleksandra Kollontai (Bloomington, 1979); Barbara Alpern Engel, Women in Russia, 1700-2000 (Cambridge, UK., 2004), plus many other books; Linda Edmondson, Feminism in Russia, 1900-17 (Stanford, 1984); Beatrice Brodsky Farnsworth, Aleksandra Kollontai: Socialism, Feminism and the Bolshevik Revolution (Stanford, 1980); Rose Glickman, Russian Factory Women: Workplace and Society, 1880-1914 (Berkeley, 1984); Adele Lindenmeyr, Poverty Is Not a Vice: Charity, Society, and the State in Imperial Russia (Princeton, 1996); Natalia Pushkareva, Women in Russian History: From the Tenth to the Twentieth Century (Gloucestershire, 1999); Irina Yukina, Russkii feminizm kak vyzov sovremennosti (St. Petersburg, 2007); Choi Chatterjee, Celebrating Women: Gender, Festival Culture, and Bolshevik Ideology, 1910-1939 (Pittsburgh, 2002); Christine Ruane, The Empire's New Clothes: A History of the Russian Fashion Industry, 1700-1917 (New Haven, 2009); Christine Worobec, Possessed: Women, Witches, and Demons in Imperial Russia (DeKalb, 2001); Melissa Kirschke Stockdale, Mobilizing the Russian Nation: Patriotism and Citizenship in the First World War (Cambridge, UK., 2016); and Elizabeth A. Wood, The Baba and the Comrade: Gender and Politics in Revolutionary Russia (Bloomington, 1997).

7. See Stites, The Women's Liberation Movement in Russia; and Grigorii Tishkin, Zhenskii vopros $v$ Rossii, 50-60-e gody XIX v (Leningrad, 1984).

8. See Sarah Badcock, Politics and the People in Revolutionary Russia: A Provincial History (Cambridge, Eng., 2007); Betsy Jones Hemenway and Elizabeth Jones Hemenway, 
Yet despite the by now extensive body of literature in Russian/Soviet women's and gender studies, women remain marginal in recent historical surveys of the revolution. More attention has been paid to the issues of citizenship, civil rights, and civil society, but the role of women as conscious political actors remains invisible in many accounts. ${ }^{9}$ Nevertheless, women's rights was one of the most divisive issues of the time, a source of conflict within all social classes, and a wedge issue for erstwhile allies in the struggle for democracy in Russia. ${ }^{10}$ In this essay I will look at themes interwoven with the history of 1917. Two, spontaneity/consciousness and class, are key elements in historical surveys of the year. One, suffrage, is not. Discussions of all three, viewed through the lens of gender, shift our understanding of the revolutionary year and Russia's place in the global context.

\section{Spontaneity/Consciousness}

Challenging the limited role assigned to women in most histories of 1917, women's history scholars have significantly contributed to understanding the gendered aspects of the revolutionary events of February. While the role of food shortages and workplace dissatisfaction in provoking and fueling the February disorders should not be minimized, this does not fully explain women's activism on International Women's Day, or subsequent days.

Were the February 23 women's demonstrations solely spontaneous bread riots? If so, what is the significance of their taking place on International Women's Day? Evidence for planning and organization complicates the usual narrative. Official accounts and revolutionary memoirs both provide clues. The Petrograd governor, A.P. Balk, received reports about several lively gatherings of "many ladies, and even more poor women (mnogo dam, esche

"Mothers of Communists: Women Revolutionaries and the Construction of a Soviet Identity," in Andrea Lanoux and Helena Goscilo, eds., Gender and National Identity in Twentieth-Century Russian Culture (DeKalb, 2006), 75-92; Sharon Kowalsky, Deviant Women: Female Crime and Criminology in Revolutionary Russia, 1880-1930 (DeKalb, 2009); Karen Petrone, The Great War in Russian Memory (Bloomington, 2011); and Laurie Stoff, Russia's Sisters of Mercy and the Great War: More than Binding Men's Wounds (Lawrence, 2015); and Laurie Stoff, They Fought for the Motherland: Russia's Women Soldiers in World War I and the Revolution (Lawrence, 2006).

9. See for example, Mark R. Baker, Peasants, Power, and Place: Revolution in the Villages of Kharkiv Province, 1914-1921 (Cambridge, Mass., 2016). A theme of this book is addressing the invisibility of the rural populations and the regions in the years of war, revolution, and civil war. But the remedy does not extend to women and gender. Peasants are presumed to be male. In the rare instance in which women are mentioned (they are not in the index), it is in passing. For example, "during the war women led almost all large-scale actions in which peasants participated, though they rarely acted alone.” The implications of women's leadership in these actions is not examined (19). In contrast, Mark Steinberg, in his The Russian Revolution, 1905-1921 (Oxford, 2017) incorporates scholarship about women and gender into his narrative rather than ignoring them or separating them from the main story.

10. For one example of the way in which the debate over women's rights contributed to the "conflict and fragmentation" of Russian educated society, see William G. Wagner, "Ideology, Identity, and the Emergence of a Middle Class," in Edith W. Clowes, Samuel D. Kassow, and James L. West, eds., Between Tsar and People: Educated Society and the Quest for Public Identity in Late Imperial Russia (Princeton, 1991), 149-63. 
bol'she bab), students, and fewer workers compared to previous demonstrations." These were not spontaneous gatherings; they were planned. Crowds formed in the center of the city, on Znamenskaia Square, Nevskii Prospekt, and at the City Duma, as well as in the workers' districts. Znamenskaia Square was near the offices of the Russian League for Women's Equal Rights. Initially, the participants were well-behaved, laughing, talking to each other, but also chanting in a restrained, plaintive way, "Bread, Bread.” Balk had no idea why the groups had gathered on that day, and why there were so many women in the crowds. ${ }^{11}$

These were not the only demonstrations. A number of commemorations of International Women's Day took place on February 23. The organized protests which surprised Balk and other tsarist officials, involved women from different classes. But there was also coordination between radical students and workers. Bolshevik worker Anna Kostina, for example, remembered that a list of speakers for International Women's Day events had already been prepared before the holiday. Requests to have them address workers' meetings were funneled through the apartment of the Bestuzhev student Tolmacheva. ${ }^{12}$

Understanding the background of International Women's Day helps explain the different February 23 demonstrations in Petrograd. The first and only socialist women's holiday was new; it had just been proclaimed on August 26, 1910. From its inception, the holiday was connected to the suffrage struggle. Searching for ways to attract more women to the cause of socialism worldwide, leading socialist women's activist Clara Zetkin called for the establishment of "a special Women's Day," whose primary purpose would be "to promote Women Suffrage propaganda," at the Second International Conference of Socialist Women, held in Copenhagen. Clara Zetkin came to view suffrage as a democratic reform advantageous to the proletariat. In naming the holiday, Zetkin used the word women, and not women workers, acknowledging that women were a separate organizing category.

Many socialist women leaders' views evolved on suffrage. Initially they were hostile, considering voting rights a "bourgeois" demand. In 1908, Aleksandra Kollontai claimed that the feminist focus on "rights and justice" was incompatible with women workers' focus on "a crust of bread." In time, noting the appeal to women workers of the suffrage movement, key activists, including Kollontai, recast the female vote as an important proletarian goal.

Russian celebrations of International Women's Day started in 1913. From the beginning, the commemoration of International Women's Day in Russia sparked conflict as activists across the feminist-socialist spectrum claimed the holiday. Feminists emphasized the cross-class organizing of women, and socialists viewed the day as a way to mobilize working-class women to join with their brothers in the revolutionary struggle. Thus, in 1917, International Women's Day already had resonance among disparate sectors of Petrograd's

11. Richard Pipes, The Russian Revolution (New York, 1990), 274; “Gibel' tsarskogo Petrograda: Fevral'skaia revoliutsiia glazami gradonachalnika A.P. Balk: Vospominaniia A.P. Balka iz arkhiva Guverskogo institute voiny, revoliutsii i mira (Stenford, SShA), 1929 g.," Russkoe proshloe 1 (1991): 7-72, 26.

12. E.N. Burdzhalov, Vtoraia Russkaia Revoliutsiia: Vosstanie v Petrograde (Moscow, 1967), 119. 
female population. Nevertheless, none of the largely male Petrograd socialist leaders expected the celebration of International Women's Day to be a catalyst for revolution.

We will never have conclusive evidence about all the factors which motivated women to take to the streets on February 23, but an exclusive emphasis on spontaneity denies the possibility that women were acting as a conscious political force. As Sarah Badcock has observed in her study of soldatki (soldiers' wives): "Sympathy offered in the democratic press to these 'poor, illiterate women' implied or stated directly that the soldatki were a wholly unconscious group, who operated only on basic instinct.... This reflects the way in which the (exclusively male) local government leaders and journalists refused to recognize soldatki as a political force in their own right." ${ }^{13}$ Badcock's analysis applies to more than the soldatki. New histories of the year must move beyond simply including a section on women and strive to integrate the majority sex as conscious political actors in 1917.

\section{Class and Gender}

A class analysis is not sufficient to explain the oppression of women, as women are in all classes, both inside the family and in the workplace. In the words of historian Hilda Smith, women "have always been close to the centers of power but prevented from exercising this power themselves." 14 Is it accurate even to use the term "bourgeois feminists," as Soviet and many western scholars were wont to do in their histories of this period? Questions of the intersection of class and gender complicate the matter for women. Can a woman automatically be assigned the same class as her husband, brother, or father? The early $20^{\text {th }}$ century conflict over extending equal rights and especially voting rights to women clearly made gender a defining issue for many women, causing them to create a different set of political priorities than many of their male kin and comrades. ${ }^{15}$

Before and certainly after the February Revolution, a growing number of women began to see the connections between their economic situation and the need for political rights. Activist Olga Zakuta, from the largest feminist organization, the League for Women's Equal Rights (hereafter the Women's League), noted that at early meetings after the February Revolution orators primarily emphasized raising women's economic status but with time, more

13. Badcock, Politics and the People in Revolutionary Russia, 67.

14. Hilda Smith, "Feminism and the Methodology of Women's History," in Berenice Carroll, ed., Liberating Women's History: Theoretical and Critical Essays (Urbana, 1976), 369-84, 374.

15. On "bourgeois feminism," see Marilyn J. Boxer, "Rethinking the Socialist Construction and International Career of the Concept 'Bourgeois Feminism," American Historical Review 112, no. 1 (February 2007): 131-58; Françoise Picq, “'Bourgeois Feminism' in France: A Theory Developed by Socialist Women before World War I," translated by Irene Ilton, in Judith Friedlander, Blanche Wiesen Cook, Alice Kessler-Harris, and Carroll Smith-Roseberg, eds., Women in Culture and Politics: A Century of Change (Bloomington, 1986), 330-343; and Ruthchild, Equality and Revolution, 55-61. 
of those at the rallies "became staunch supporters of women's participation in the Constituent Assembly."16

As I have noted in my own work, dissatisfaction over the failure of the Provisional Government to act quickly and decisively on the issue of suffrage led to the second major foray of women into the public arena. On March 19, three weeks after the abdication of Tsar Nicholas II, Poliksena ShishkinaIavein, President of the Women's League, organized the largest women's demonstration in Russian history, demanding suffrage. An estimated thirtyfive to forty thousand women took part. The march, led by Shishkina-Iavein and revolutionary heroine Vera Figner, began at the City Duma on Nevskii Prospekt, in the heart of the city, and headed toward the State Duma, at the Tauride Palace. Ninety organizations joined in sponsoring the demonstration. By the end of the day, Soviet and Provisional Government leaders agreed to extend suffrage to women. ${ }^{17}$

Pictures and a newsreel of the March 19 demonstration show clearly that this was a cross-class crowd. Those wearing hats and those wearing kerchiefs mingled freely among the demonstrators. The march was not, as some historians have argued, merely a momentary diversion from working women's class-driven politics. As I will discuss more in the next section, suffrage was an issue of importance throughout most of $1917 .^{18}$

Historians of 1917 have also failed to understand the significance, range, and impact of feminist leaders' politics. It is simply not true (as Rex Wade argues in his otherwise important history of the Russian Revolution) that most leaders were "closely identified with the Kadet Party, and were either suppressed or forced to flee the country after 1917." ${ }^{19}$ In fact, the feminists were not monolithic; many identified as socialists. A majority of the leaders stayed in Russia, often working as physicians or teachers. Some were later honored by the Soviet government.

The leaders of the feminist movement were largely part of a new, emerging group, the female intelligentsia. Given the relatively recent availability of higher education opportunities for women, they were likely the first females

16. Olga Zakuta, Kak v revoliutsionnoe vremia vserossiiskaia liga ravnopraviia zhenshchin dobilas' izbiratel'nykh prav dlia russkikh zhenshchin (Petrograd, 1917). For a complete English translation of this pamphlet, see "Kak $v$ revoliutsionnoe vremia vserossiiskaia liga ravnopraviia zhenshchin dobilas' izbiratel'nykh prav dlia russkikh zhenshchin (How in the revolutionary time the All-Russian League for Women's Equal Rights won suffrage for Russian women)," Intro. and Trans. by Rochelle Goldberg Ruthchild, Aspasia 6 (2012): 117-24.

17. Liubov Gurevich, Pochemu nuzhno dat' zhenshchinam takiia zhe prava, kak muzhchinam (Petrograd, 1917), 2; Irina Yukina and E. Guseva, Zhenskii Peterburg: Opyt istorikokraevedcheskogo putevoditelia (St. Petersburg, 2004) 13, 261.

18. Stephen A. Smith, in his recently published history of 1917, argues that the March 19 demonstration was "a rare moment when gender rather than class was the axis of organization.” See: Stephen A. Smith, Russia in Revolution: An Empire in Crisis, 1890 to 1928 (Oxford, 2017), 140. Other scholars have made similar arguments. Barbara Alpern Engel in her survey Women in Russia argues that: "When in the aftermath of the February Revolution lower-class women grew more assertive, they rarely pursued women's political rights as such. ...” (Engel, Women in Russia,1700-2000,134). For more coverage of the suffrage struggle, see Clements, A History of Women in Russia from Earliest Times to the Present, $182-84$.

19. Rex Wade, The Russian Revolution, 1917, $3^{\text {rd }}$ ed., (Cambridge, Mass, 2017), 123. 
in their families to attend or complete medical or university courses. Seeking higher education, or any education, challenged traditional notions of women's roles in family and society. For many, enrolling in a higher education course was their initial act of rebellion. Often their families were opposed "to girls running through the streets to some kind of unthinkable knowledge," as one feminist reminisced. ${ }^{20}$

Still, the intelligentsia were a small part of the population, no more than about ten thousand in an overall female population of sixty-three million at the turn of the twentieth century. Judging by the size of demonstrations, and the Constituent Assembly popular vote, the appeal of political rights for women extended across the country, to workers and to peasants far from the metropolitan centers. This was not an issue which died after one demonstration. ${ }^{21}$

\section{Women's Suffrage}

Women's suffrage appealed to a broad range of activists throughout 1917. As mentioned above, the newsreel of the March 19 women's suffrage demonstration shows the intersectionality of the feminist appeal, with women from the working and middle classes marching. Socialists reframed suffrage as support for the revolutionary female proletariat. ${ }^{22}$ In her first article for Pravda, Aleksandra Kollontai, recently returned from exile on March 18, argued for the female vote as a reward for women's activism: “Weren't we women first out on the streets? Why now ... does the freedom won by the heroic proletariat of both sexes, by the soldiers and soldiers' wives, ignore half the population of liberated Russia?” Among the masses, suffrage as an issue resonated among both women and men, and all over revolutionary Russia. Meetings demanding women's suffrage were so popular that at some places the halls had to be emptied three times to accommodate all those who wished to hear the speakers. Women workers in Kostroma and Iaroslavl, in the Russian heartland, joined equal rights organizations. In Siberia, an Irkutsk meeting of three thousand women and men sent a telegram to the Provisional Government demanding full electoral rights for women in the Constituent Assembly. Typical was a call to women in Khabarovsk to "take part in the creation of a free Russia," unite, and form a women's union. At one of the many meetings, a union of soldiers' wives emerged. Slogans supporting women's suffrage appeared at a number of large demonstrations. ${ }^{23}$

20. Ekaterina Shchepkina, cited in Ruth Arlene Fluck Dudgeon, "Women and Higher Education in Russia, 1855-1905” (Ph.D. Dissertation, George Washington University, 1975), 109.

21. Ruthchild, Equality and Revolution, 58.

22. The Merriam-Webster definition of intersectionality applies here: "It's been around since the late 1980's but intersectionality is a word that's new to many of us. It's used to refer to the complex and cumulative way that the effects of different forms of discrimination (such as racism, sexism, and classism) combine, overlap, and yes, intersect-especially in the experiences of marginalized people or groups." See: "Word We're Watching: Intersectionality," Merriam Webster, at www.merriam-webster.com/words-atplay/intersectionality-meaning (last accessed July 6, 2017)

23. For the film of the suffrage march, see: "1917 Petrograd March for Women's Suffrage," YouTube video, 4:13, from the Russian Archives of Films and Photographs, posted 
Compared to the leaders of the major western democracies, the Provisional Government and Soviet leaders acceded quickly to demands to extend the franchise to women. In the US and Britain, countless suffrage demonstrations, petitions, referenda, as well as militant actions achieved little. Several factors explain the more progressive Russian response. Unlike politicians in many of the older democracies, neither the Provisional Government nor the Soviet leaders were anti-women's suffrage. Even those who, like the Kadet leader Paul Miliukov, initially opposed the female vote, had long since changed their positions. Support for women's rights had become standard in the platforms of socialist and other parties on the left. More conservative members of the government, like Rodzianko, now recognized that women's suffrage was part of what defined the modern state. ${ }^{24}$

Revolutionary Russia was more advanced in extending suffrage than any of its wartime allies. British women over thirty won limited, property-based suffrage in 1918 and didn't win universal suffrage for females aged twentyone and over until 1928. French women won the vote only in 1944. In the US, President Woodrow Wilson was quick to restrict rights, approving the segregation of government offices beginning in 1913, but slow to endorse the female vote. As Russian women were gaining the vote, suffragists picketing outside the White House with signs comparing "Free Russia" with the US, were being arrested and jailed under the Espionage Act of 1917. Wilson did not declare his support for the women's suffrage amendment until January 9, 1918, and American women formally won suffrage only in $1920 .{ }^{25}$

In 1917, Russian women took to using their new rights in great numbers. Their voting rates in the first election in which they had the franchise compare quite favorably with the US. The Constituent Assembly elections, starting on November 12 and extending in some places into 1918, were the first elections in which Russian women over the age of twenty could vote and run for

by "Davis Center for Russian and Eurasian Studies," March 27, 2013, at www.youtube. com/watch? $\mathrm{v}=$ LLOQASmngrE (last accessed July 6, 2017). For the Kollontai quote, see: Ruthchild, Equality and Revolution, 225. See also Ann Bobroff, "The Bolsheviks and Working Women, 1905-1920," Soviet Studies 26, no. 4 (1974): 540-67, 558, 560, and Ann Bobroff-Hajal, Working Women in Russia under the Hunger Tsars: Political Activism and Daily Life (Brooklyn, 1994), 91. On the Khabarovsk meetings and demonstrations, see Pavel Shcherbinin, Voennyi faktor $v$ povsednevnoi zhizni russkoi zhenshchiny $v$ XVIII-nachale XXv. (Tambov, 2004), 475.

24. Rodzianko had experienced the wrath of the Tsar on the issue of universal suffrage. The autocrat remained opposed to full suffrage and further democratic reforms even at a time of utmost peril to his rule. Immediately after the start of the February Revolution, Rodzianko met with the Tsar on March 3, 1917, presenting him with a proposal for elections to a Constituent Assembly based on the four tail formula. The Tsar rejected it out of hand, writing in his diary: “God knows who thought up such nonsense!” See: Nikolai Alexandrovich Romanov, Dnevniki Imperatora Nikolaia II, ed. K. F. Shchhatsillo, B. P. Kozlov, T.F. Pavlova, and Z. I. Peregudova, (Moscow, 1991), 625.

25. Eleanor Flexner, Century of Struggle: The Woman's Rights Movement in the United States (Cambridge, 1959), 1975, 294-95 on women picketing and getting arrested; 301 on Wilson's declaration of support. On Wilson and government segregation, see Dick Lehr, "The Racist Legacy of Woodrow Wilson," The Atlantic, November 27, 2015, at www. theatlantic.com/politics/archive/2015/11/wilson-legacy-racism/417549/ (last accessed July 6, 2017). 
office, the freest elections ever held in Russia until after the collapse of the Soviet Union in 1991 . Over forty million votes were cast. ${ }^{26}$ The voter participation rate was estimated by Oliver Radkey to be about fifty-five percent. This is remarkable given the chaos and uncertainty of the period, immediately after the Bolshevik seizure of power in October. ${ }^{27}$ Nevertheless, Russian women in the wartime conditions of 1917 went to the polls at higher rates than their US counterparts. The US held its first national election in which (mostly white) women voted, in peacetime. Jim Crow restrictions for both African-American women and men limited their overall vote until 1965. Native American women and men did not win voting rights in all states until 1962. Scholars of the US Presidential election of 1920 estimate that the female turnout averaged about $37 \%$, while men's participation averaged about $55 \%{ }^{28}$

Women's suffrage is one of the great democratic reforms of the twentieth century. It is the logical extension to women of the rights of citizenship articulated by the French and American Revolutions and over the nineteenth century given to all men in most western countries. Revolutionary Russia pioneered in extending suffrage to women. And even though elections in the Soviet one-party state were largely a sham, voting was retained as a hallmark of a modern state. Given the increased scholarly attention to the question of citizenship and civil society in early twentieth-century Russia, an analysis of the role of women's suffrage and women's rights as motivating issues, their intersectionality, their place in the 1917 revolutions, and their domestic and international impact, is important in complicating and filling in the full history of this revolutionary year. Suffrage as a motivating factor for women's entry into the public sphere can be seen from the outbreak of revolution, on International Women's Day, through the demonstrations which culminated in Russian women winning the vote, to the actualization of this right in local and then national political participation through the Constituent Assembly.

In sum, issues such as political consciousness, class, citizenship, and suffrage, all of which became especially significant in the revolutionary outbreak and the unfurling of events in 1917, cannot be understood without reference to the role of women and gender. It behooves us as historians, especially as the current Kremlin ruler seeks to downplay the 1917 revolutions and encourage a return to "traditional values" in all areas, to provide the most accurate information we can about the events of that year and the progressive democratic movements which emerged then, even if they were eventually vanquished. ${ }^{29}$

26. Mark Vishniak, Vserossiiskoe uchreditel'noe sobranie (Paris, 1932), 83.

27. For the Constituent Assembly election participation figures, see Oliver Radkey, Russia Goes to the Polls: The Elections to the All-Russian Constituent Assembly, 1917 (Ithaca, 1989), 44-45.

28. J. Kevin Corder and Christina Wolbrecht, Counting Women's Ballots: Female Voters from Suffrage through the New Deal (New York, 2016), 137.

29. Neil MacFarquhar, “'Revolution? What Revolution?’ Russia Asks 100 Years Later,” New York Times March 11, 2017, A1, A8. 